\title{
Remediation of Petroleum Polluted Site in Nigeria Using Granulated Activated Carbon (Gac)
}

\author{
${ }^{1}$ Ameh, C.U., ${ }^{2}$ Jimoh, A., ${ }^{3}$ Abdulkareem, A.S. and ${ }^{4}$ Otaru, A.J. \\ ${ }^{1}$ (Chevron Nigeria Limited, 2, Chevron Drive, Lekki, Lagos, Nigeria). \\ ${ }^{2,3 \& 4}$ (Department of Chemical Engineering, Federal University of Technology, Minna, Nigeria)
}

\begin{abstract}
Nigeria is a country prone to soil and water pollution resulting from the activities of the Oil and Gas industry. Remediating the polluted soil is very important hence the use of Granular Activated Carbon. Characterization of the soil samples before and after pollution was carried out using AOCS 1986 standard. Characterization of the commercially obtained Granular Activated Carbon before and after use was done using cultured Pseudomonas Putida. The remediation experiment was carried out for 14 days at temperatures of 30 , 35 , 40 and $45^{\circ} \mathrm{C}$ with the initial total temperature and soil sample quantity valued to be $25 \mathrm{mg} / \mathrm{L}$ and $500 \mathrm{~g}$. Graphical representation of remediation at different temperatures show that microbial degradation increases as temperature increases. The microbial degradation increases as temperature increases. The moisture content of the soil also decreases as temperature increases. Hence, hydrocarbon pollution leads to corresponding environmental impact on the soil which can be remediated by the use of Granular Activated Carbon (GAC).
\end{abstract}

Keywords: GAC, Nigeria, Petroleum, Pollution and Soil.

\section{Introduction}

According to Achebe et al (2012), pipeline failure is one of the major causes of oil spillage in Nigeria. The failures result from age, vandalism and illegal bunkering with devastating environmental consequences. Zabbey (2009) outlined the impact of the about 273 spills that occur annually in Nigeria resulting in an average deposit of 115,000 barrels of crude into the environment. Fifty percent of the over 4000 oil spills in Nigeria since 1960 have been as a result of pipeline corrosion, 28 percent resulted from sabotage while 21 percent were the consequences of operational activities (Oloruntegbe et al, 2009).

Many major oil spill incidents have occurred in various parts and at different times along Nigeria coast. Some of these major reported spills include the Chevron's Escravos spill of 1978 that involve about 300,000 barrels (Zabbey, 2009; Ugochukwu, 2008); Shell Petroleum Development Company's Forcados Terminal tank failure also in 1978 with about 580,000 barrels (Zabbey, 2009; Steiner, 2008) and the Texaco Funiwa-5 blow-out of 1980 with about 400,000 barrels (Aghalino \& Eyinla, 2009; Oruonye, 2012). Other major oil spill incidents include the Jesse Fire Incident which claimed about a thousand lives in Jesse, Delta State in 1998 (Nwilo \& Badejo, 2005) and the most recent Chevron Funiwa blow out leading to two fatalities and the KS Endeavour rig being burnt to the ground (Price Forbes, 2012; Blowout, 2012). Considering the high volume of oil spilled as a result of exploitation and exploration activities and the negative impact on the ecosystem necessitating, there is the need for urgent cleaning of the polluted sites immediately the spillage occurs. The most effective methods through which this can be achieved is by using remediation techniques.

On the use of remediation techniques, a whole series of approaches have been discussed in literatures (Castelo-Grande et al., 2010), ranging from capping (Lowry et al., 2006; Murphy et al., 2006), locking (Ying et al., 2005; Bartelt-Hunt et al., 2006), over phytoremediation (Erakhrumen, 2007), in situ chemical treatment (Olexsey \& Parker, 2006), use of activated carbon (Vasilyeva et al, 2006) to dredging and excavation (Bes and Mench, 2008). Among all these, the use of activated carbon (AC) has proven to be one of the best adsorbents for organic pollutants due to its hydrophobicity, and microporous structure (Vasilyeva et al, 2006).

The need for a clean soil need not be overemphasized especially in this era of economic diversification from oil over-dependence as a sole source of generating revenue in developing nation like Nigeria. This research is partly motivated by the need to preserve the natural properties of the soil in order to have available soil for the purpose of agriculture, infrastructural development, etc. This research work therefore looks into remediation of petroleum polluted site in Nigeria using granular activated carbon (GAC).

Materials and Chemicals:

\section{Research Methodology}

The major materials used for this research included crude oil sample, acquired from Obagi Flow station of Total Nigeria Limited; specified quantity of Pseudomonas putida bacteria, cultured from a remediated site at Isiokpo in Ikwerre LGA of Rivers State and Granular Activated carbon (GAC), obtained commercially. The materials, apparatus and reagents used are as listed in Tables 1 and .2 and listed below; 
1. Glass Adsorption Column [Erlenmeyer flask

2. Bioreactor set up

3. Spectrophotometer [HITACHI Model U-2001]

4. Analytical Weighing Balance

5. Petridish

6. Hexane

7. Desiccators for sample drying

8. Autoclave machine for temperature regulation

9. Distilled Water;

10. Samples of virgin activated carbon

11. Samples of polluted activated carbon

12. $\mathrm{pH}$ meter used during characterization of activated carbon and soil samples.

Table 1: List of Materials and Chemicals used

\begin{tabular}{rccc}
\hline S/No & Material/Chemical & Source & Quantity used \\
\hline 1. & Hexane & Commercial & 10 litres \\
2. & Crude Oil & Obagi Flow & 10 gallons \\
& station & \\
3. & Granular Activated Carbon & Commercial & $5 \mathrm{~kg}$ \\
4. & Distilled water & Commercial & 20 litres \\
5. & Pseudomonas Putida & Commercial & 20 centilitres \\
\hline
\end{tabular}

\section{Equipment}

\begin{tabular}{cccc}
\multicolumn{4}{c}{ Table 2 List of Equipment used } \\
\hline S/No & Equipment & Model/Year & Manufacturer \\
\hline 1. & Analytical balance & AAA250LE/ 2000 & AE ADAMS \\
2. & Autoclave & YXQ-LS-75/ 2005 & SHANGAI BOXUM \\
& & INDUSTRY \&COMM CO \\
& & LTD \\
3. & Smart pH meter & SM101/ 2005 & MILWAUKEE \\
4. & Spectrophotometer & NV203/ 2005 & INSTRUMENTS \\
& CECIL INSTRUMENTS \\
5. & Bioreactor & TDScan WP1/ 2002 & EUTECH \\
& & & INSTRUMENTS PTE \\
& & & LTD \\
\hline
\end{tabular}

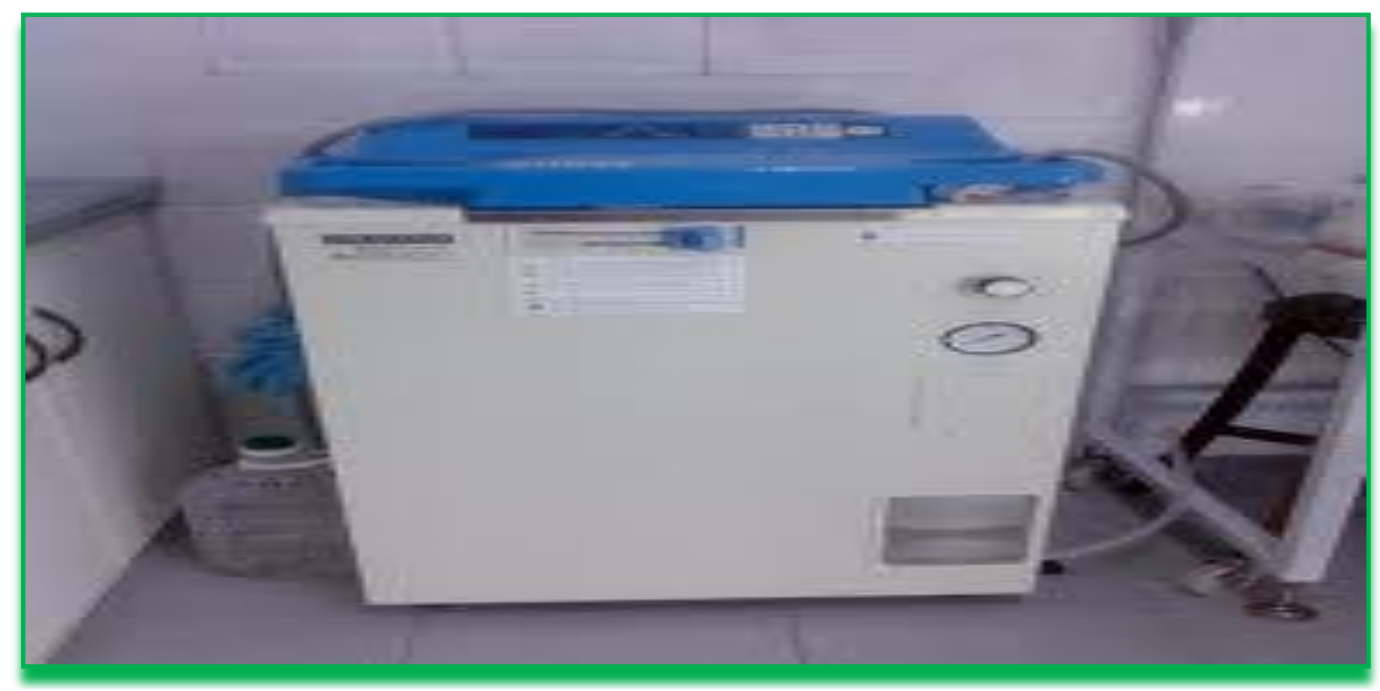

Plate I: Autoclave Machine 


\section{Characterization of Samples}

Commercially obtained adsorbent used in this research work (Granular Activated Carbon) was characterized to determine its pore volume, surface area, chemical composition, bulk density, $\mathrm{pH}$, moisture content and ash content.

\section{Sample Preparation}

1. $\mathrm{SnCl}_{2}$ :- Dissolve $5 \mathrm{~g}$ of $\mathrm{SnCl}_{2}$ in $10 \mathrm{mls}$ of $\mathrm{HCl}$ and $90 \mathrm{mls}$ of diluted water.

2. $\mathrm{K}_{2} \mathrm{Cr}_{2} \mathrm{O}_{7}$ :- Dissolve $2.5 \mathrm{gms}$ of $\mathrm{K}_{2} \mathrm{Cr}_{2} \mathrm{O}_{7}$ in 1 litre of distilled water.

3. Barium diphenylamine sulfonate indicator: Dissolve $1 \mathrm{~g}$ of barium diphenylamine sulfonate indicator in $100 \mathrm{mls}$ conc. $\mathrm{H}_{2} \mathrm{SO}_{4}$.

4. $\mathrm{HgCl}_{2}$ :- Dissolve $\mathrm{HgCl}_{2}$ (any quantity) to saturation point in distilled water.

\section{Study Site Preparation}

A study site was created by selecting a non-polluted land (loose soil) as experimentation field. Selected sections of the site were polluted with crude oil (hydrocarbon) of different concentrations $(250 \mathrm{ml}, 300 \mathrm{ml}$ and $350 \mathrm{ml}$ ), after which it was left to incubate for 9 days. The soil sample of the site was characterized and analyzed before and after being contaminated with hydrocarbon (crude oil) for the presence and concentration of hydrocarbon. The field used is located at Nkpolu-Oroworukwo, Port Harcourt LGA of Rivers State.

\section{Experimental summary}

Three (3) samples of polluted soil of different concentration of hydrocarbon were treated with virgin activated carbon. Characterization of the soil and granular activated carbon were carried out by determining the following; ferric oxide (ASTM C114-61), ash content (Pearson, 1981), moisture \& volatile matter (AOCS, 1986), soil pH (GTM-24 method), bulk density (ASTM D4292), pore volume (ASTM D3037), organic carbon content (ASTM E1195-01), acidity content (ASTM D1067), soil phosphorus (ASTM D2795), total hydrocarbon content (ASTM D7678), sulphate content (ASTM D2795) and chloride content (ASTM D4327). The optimum degradation temperature was determined from literature. The total hydrocarbon concentration of the used activated carbon was determined and the saturated activated carbon was extracted from the soil sample using a physical sieve of $1.7-2.4 \mathrm{~mm}$. This is necessary because the particles size of granular activated carbon is larger than the soil granules.

\section{Results and Discussions}

Environmental pollution is one of the major hazards facing humanity today. In Nigeria, the activities of oil exploration and exploitation have repeatedly exposed the environment to the effect of hydrocarbon spill. Remediation involves the treatment of polluted sites in attempt to return them to pre-pollution state. The use of Granular Activated Carbon is one of the methods in achieving site remediation. It can also be used in the removal of organic constituents in waste water due to the important advantage of not adding anything detrimental to the water (DeSilva, 2000).

\section{Characterization of Soil Sample}

The following results were obtained experimentally in the process of characterization of the soil prior to pollution, after pollution, characterization of GAC before and after use, the remediation exercise.

Table 3 shows the results of the soil characterization before being polluted with hydrocarbon. The $\mathrm{pH}$ value of the three soil samples were 6.51, 6.50 and 6.49 respectively for samples A, B and C. The ASTM standard for soil sample should be greater than 5 . The percentage chloride and sulphate content for samples A, B and $\mathrm{C}$ were obtained as 0.03 and $0.26,0.029$ and $0.24,0.027$ and 0.28 respectively. The ASTM standards for both are 1 and 0.4 respectively. The bulk density result for samples A, B and C were obtained as 1152.6, 1153.0 and $1152.7 \mathrm{~kg} / \mathrm{m}^{3}$ respectively falling within the ASTM range of $1100-1800 \mathrm{~kg} / \mathrm{m}^{3}$.

The Total Hydrocarbon Content (THC) percentage of soil sample A, B and C were measured to be 0.9, 0.9 and 0.95 respectively. The percentage organic carbon content of the samples were 4.07, 4.10 and 4.08 for samples A, B and C respectively and this aligns with the ASTM standard value of 5 . The percentage soil acidity of the three samples were measured to be $0.18,0.17$ and 0.19 for A, B and C and this also falls within the ASTM standard value of 2.0.

The percentage phosphorus and ferric oxide content in soil samples A, B and C as measured were 0.03 and 1.08, 0.036 and 1.10, 0.038 and 1.13 in alignment with the ASTM standard of 0.5 and 5.0 respectively. In comparison, soil sample B had the highest $\mathrm{pH}$ and bulk density. Plates II, III and IV pictorially show the structure of the three soil samples before pollution. 
Remediation Of A Petroleum Polluted Site In Nigeria Using Granulated Activated Carbon (Gac)

Table 3 Results for soil sample characterization before pollution

\begin{tabular}{llccccc}
\hline & S/No & Property & Unit & & SAMPLE & ASTM \\
\cline { 1 - 4 } & & & $\mathrm{A}$ & $\mathrm{B}$ & $\mathrm{C}$ & $\begin{array}{c}\text { Standard } \\
1 .\end{array}$ \\
2. & $\mathrm{pH}$ & - & 6.51 & 6.50 & 6.49 & $>5$ \\
3. & $\mathrm{Cl}^{-}$ & $(\%)$ & 0.03 & 0.029 & 0.027 & 1 \\
4. & $\mathrm{SO}_{4}{ }^{2-}$ & $\left(\mathrm{kg} / \mathrm{m}^{3}\right)$ & 1152.6 & 1153.0 & 1152.7 & $1100-1800$ \\
5. & Bulk Density & $(\%)$ & 0.9 & 0.9 & 0.95 & 20 \\
6. & THC & $(\%)$ & 4.07 & 4.10 & 4.08 & 5 \\
7. & Organic & & & & & \\
8. & Carbon & $(\%)$ & 0.18 & 0.17 & 0.19 & 2.0 \\
9. & Acidity & $(\%)$ & 0.03 & 0.036 & 0.038 & 0.5 \\
\hline
\end{tabular}

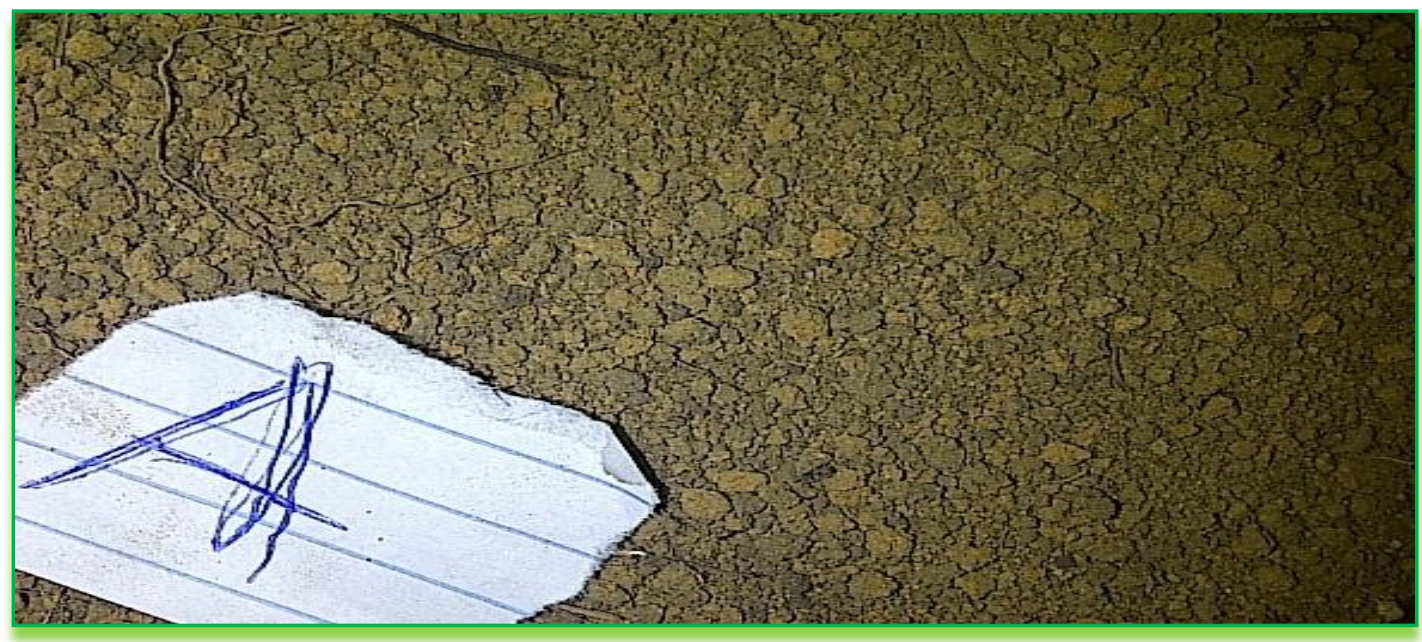

Plate II: Soil sample A before pollution

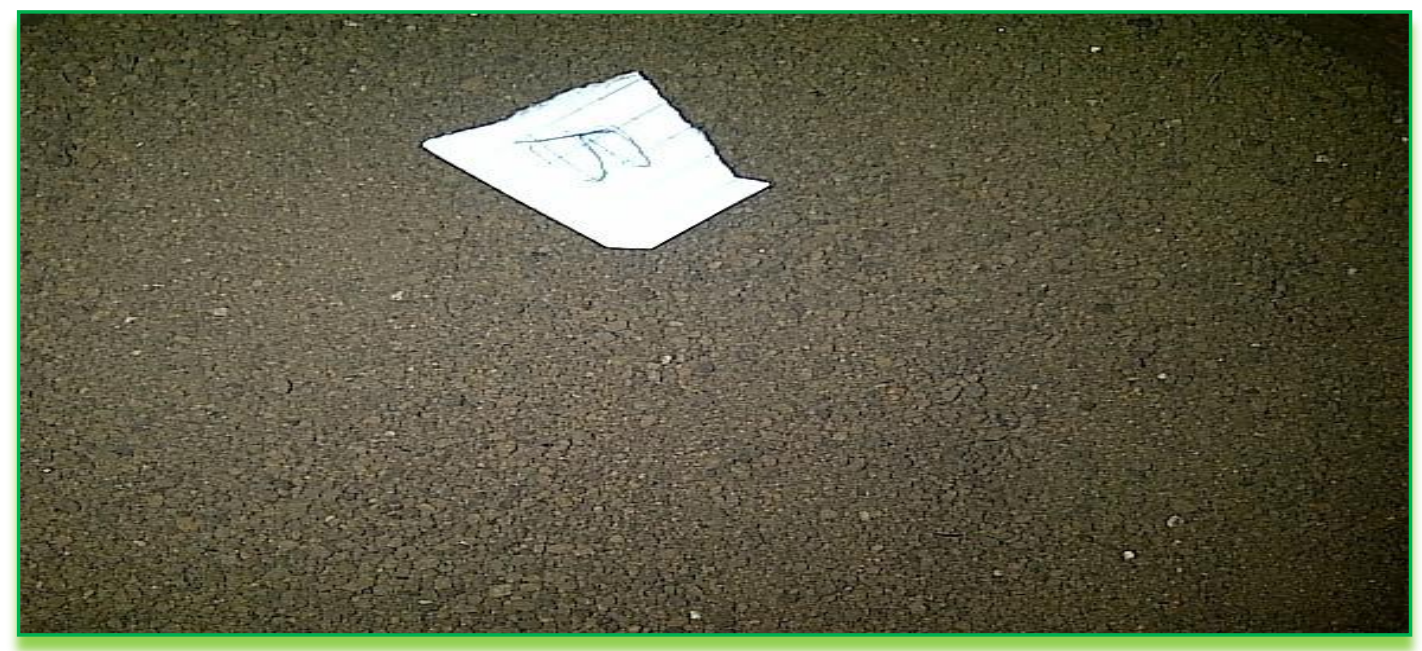

Plate III: Soil sample B before pollution 


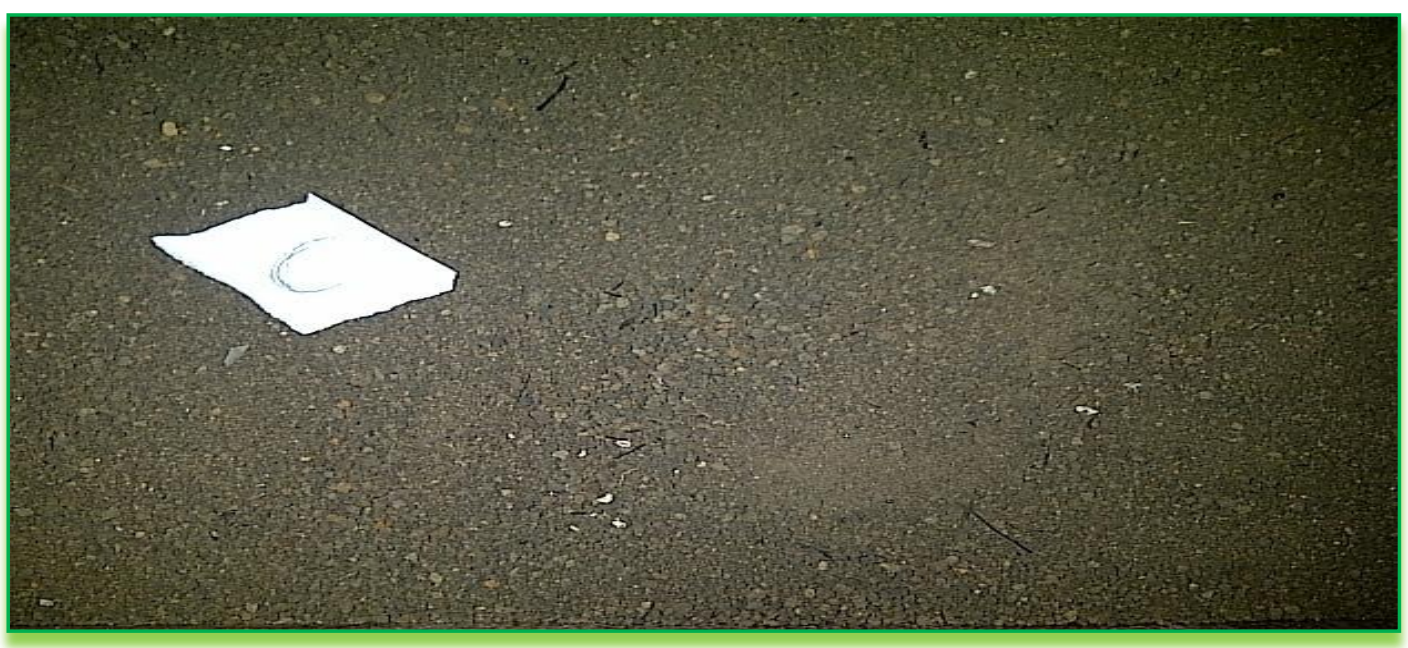

Plate IV: Soil sample C before pollution

Table 4 contains the result of the characterization of the same soil samples A, B and C after being polluted with hydrocarbon. Sample A was polluted with $200 \mathrm{ml}$ of hydrocarbon, B with $250 \mathrm{ml}$ and C was polluted with the highest volume of hydrocarbon $(300 \mathrm{ml})$ leading to a corresponding increase in the percentage of THC of samples A, B and C to $31.74,39.88$ and 40.13 respectively.

The $\mathrm{pH}$ value of the three soil samples considerably decreased after pollution to 5.18, 5.14 and 5.08 respectively for samples A. B and C. This is a pointer to the impact of hydrocarbon on the acidity of soil as it prevents leaching of basic salts as well as leads to production of organic acids (Mbhele, 2007; Nwoye \& Osuji, 2007). The chloride and sulphate content of the soil increased to $0.44,0.46$ and 0.51 respectively for samples A, $\mathrm{B}$ and $\mathrm{C}$ which is consistent with the impact of hydrocarbon and its constituents on the soil. The bulk density of soil samples A, B and C increased as indicated in the measured results of $1272.94,1273.60$ and $1273.61 \mathrm{~kg} / \mathrm{m}^{3}$ respectively. The percentage organic content for the samples was obtained as $6.88,6.93$ and 6.95 which is a significant increase from the values before pollution. The acidity of the three soil samples increased as can be deduced from the decrease in $\mathrm{pH}$ value mentioned above. The percentage acidity values obtained were 3.35 , 3.37 and 3.39 respectively. The percentage phosphorus and ferric oxide content results obtained were 4.94 and 5.22, 5.08 and 5.26, 5.14 and 5.28 respectively and this also indicates a tremendous increase over the initial results. The presence of hydrocarbon in the soil can be concluded to be responsible for the significant alteration of the assessed parameters for the soil samples.

Plates V, VI and VII pictorially shows the structure of the soil samples after being polluted with the hydrocarbon. Plates VIII, IX and X pictorially shows the structure of the soil samples on the fifth of the nine days used for incubation before commencement of remediation using GAC.

Table 4 Results of soil sample characterization after pollution

\begin{tabular}{cccccc}
\hline S/No & & $\mathrm{A}$ & $\mathrm{B}$ & $\mathbf{C}$ & $\begin{array}{c}\text { ASTM } \\
\text { Standards }\end{array}$ \\
\hline 1 & & & & \\
2 & $\mathrm{pH}$ & 5.18 & 5.14 & 5.08 & $>5$ \\
3 & $\mathrm{Cl}^{-}(\%)$ & 0.44 & 0.46 & 0.51 & 1 \\
4 & $\mathrm{SO}_{4}{ }^{2-}(\%)$ & 0.48 & 0.53 & 0.59 & 0.4 \\
5 & $\mathrm{THC}$ & 31.74 & 39.88 & 40.13 & 20 \\
6 & Bulk density (kg/m3) & 1272.94 & 1273.60 & 1273.61 & $1100-1800$ \\
7 & Organic carbon (\%) & 6.88 & 6.93 & 6.95 & 5 \\
8 & Acidity (\%) & 3.35 & 3.37 & 3.39 & 2.0 \\
9 & Phosphorous (\%) & 4.94 & 5.08 & 5.14 & 0.5 \\
10 & Ferric oxide (\%) & 5.22 & 5.26 & 5.28 & 5 \\
& Organic imprints & Brown & Brown & Brown & \\
\hline
\end{tabular}




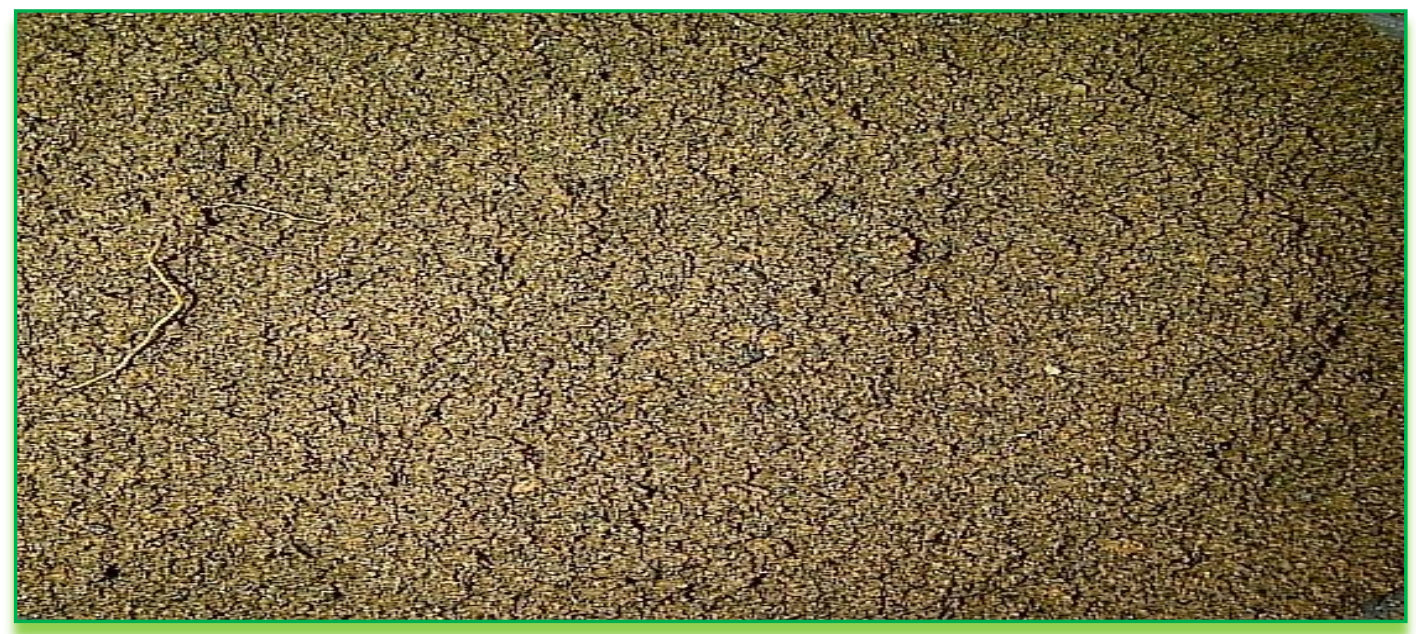

Plate V: Soil sample A after pollution

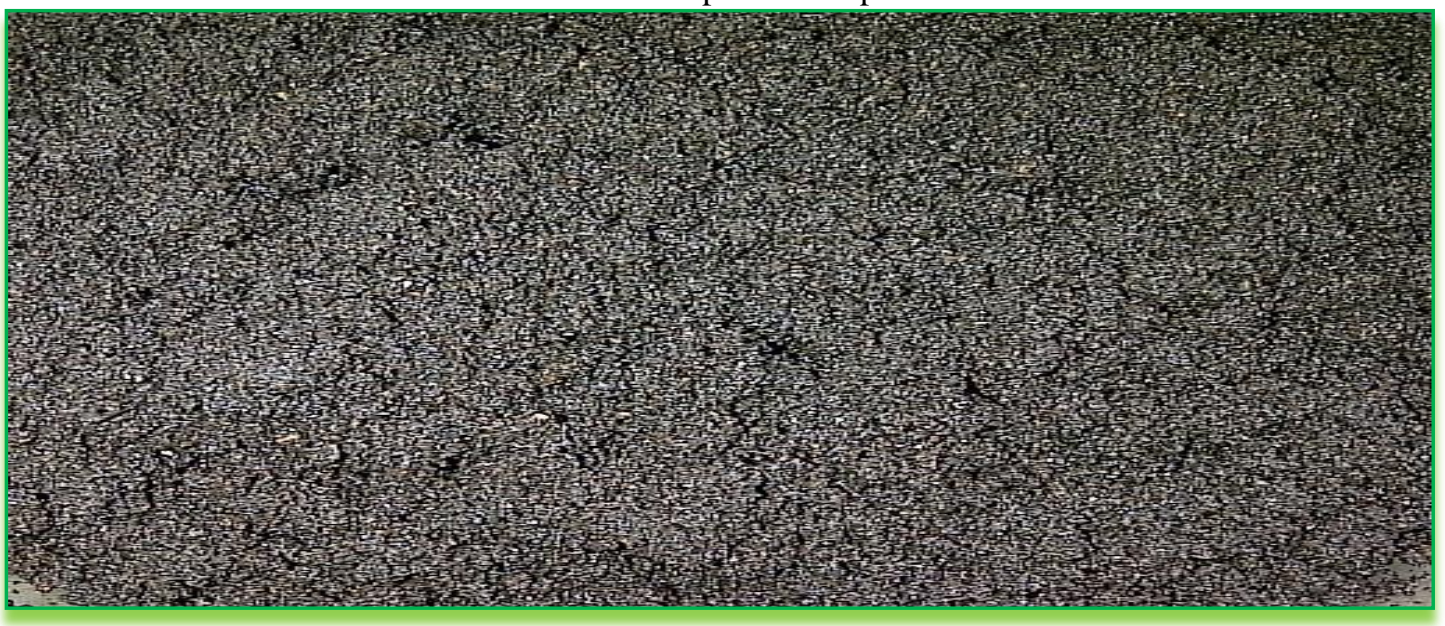

Plate VI: Soil sample B after pollution

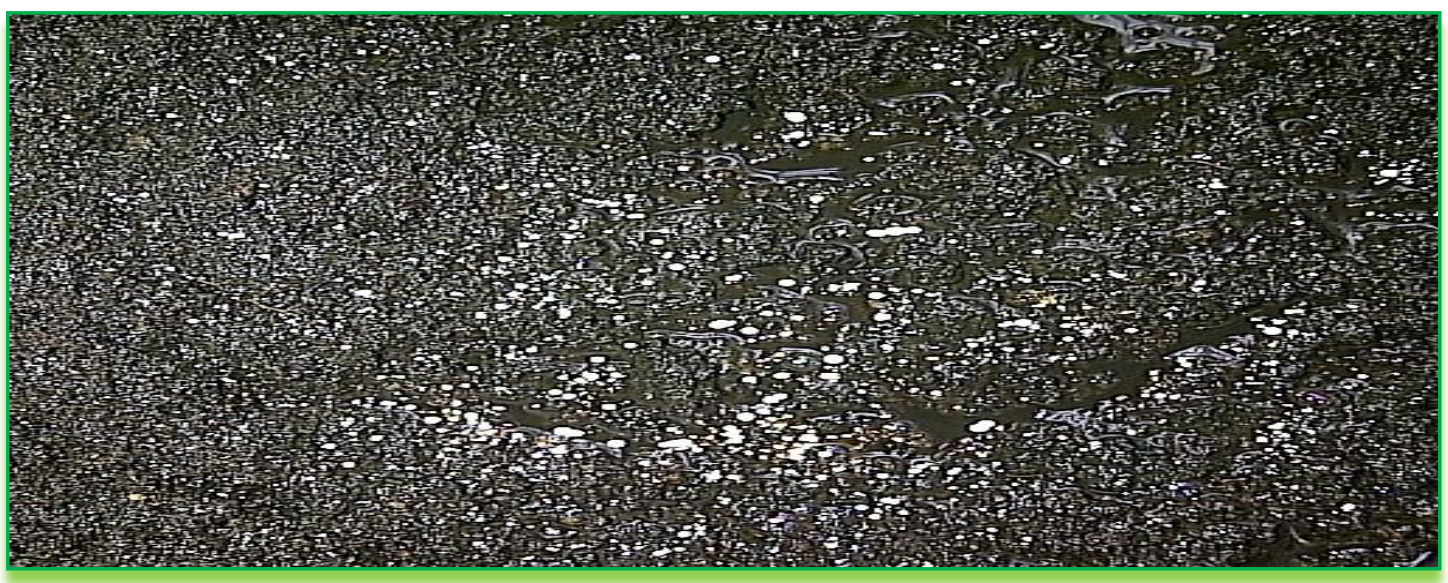

Plate VII: Soil sample C after pollution 


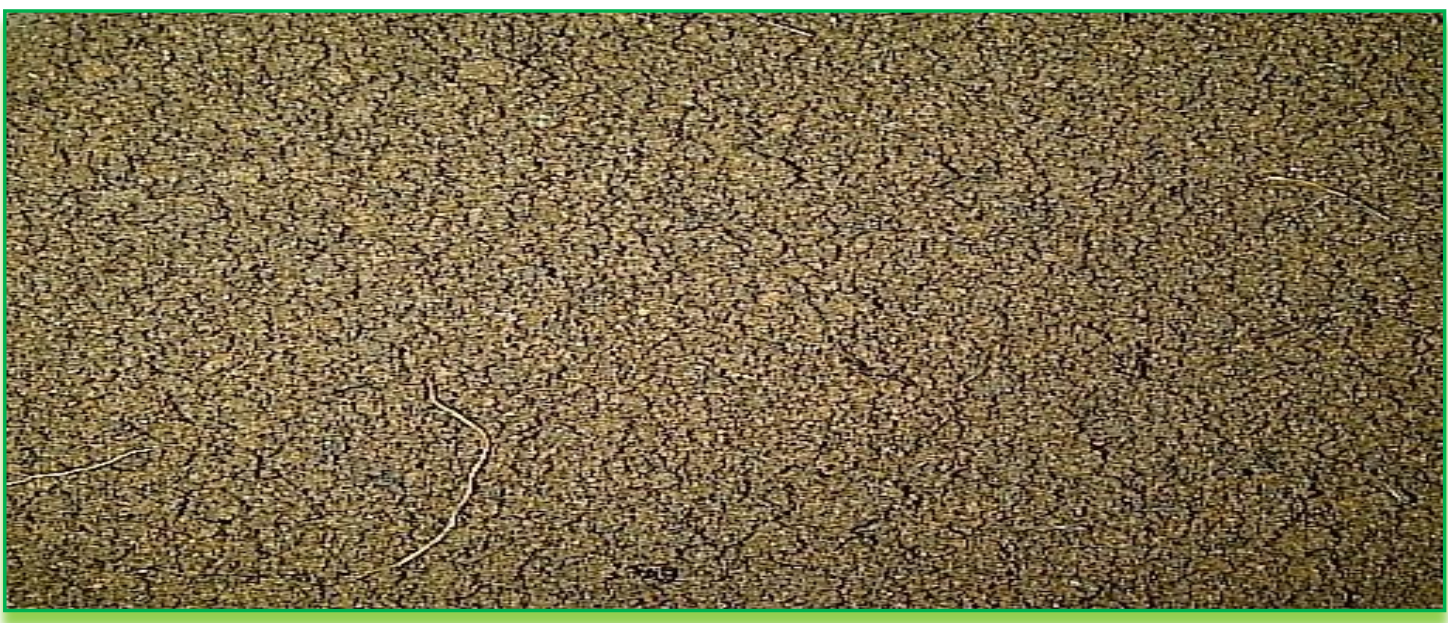

Plate VIII: Soil sample A on the fifth day of incubation

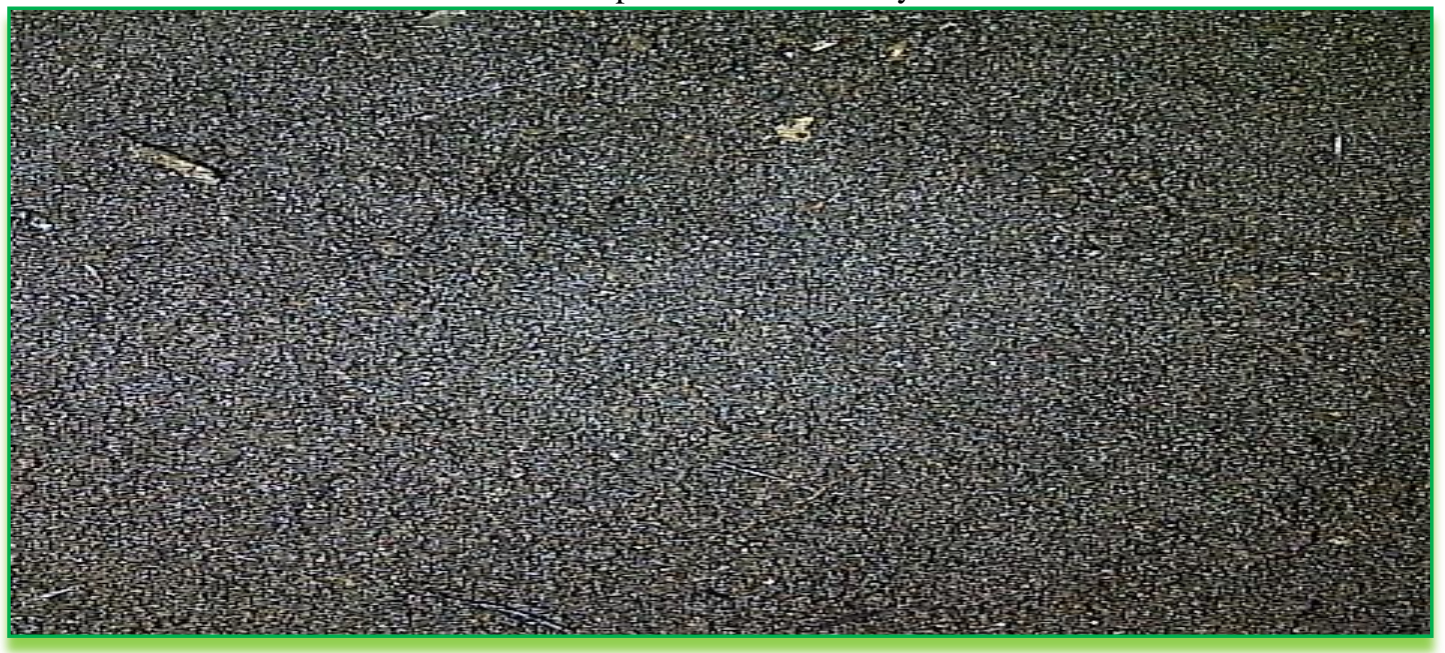

Plate IX: Soil sample B on the fifth day of incubation

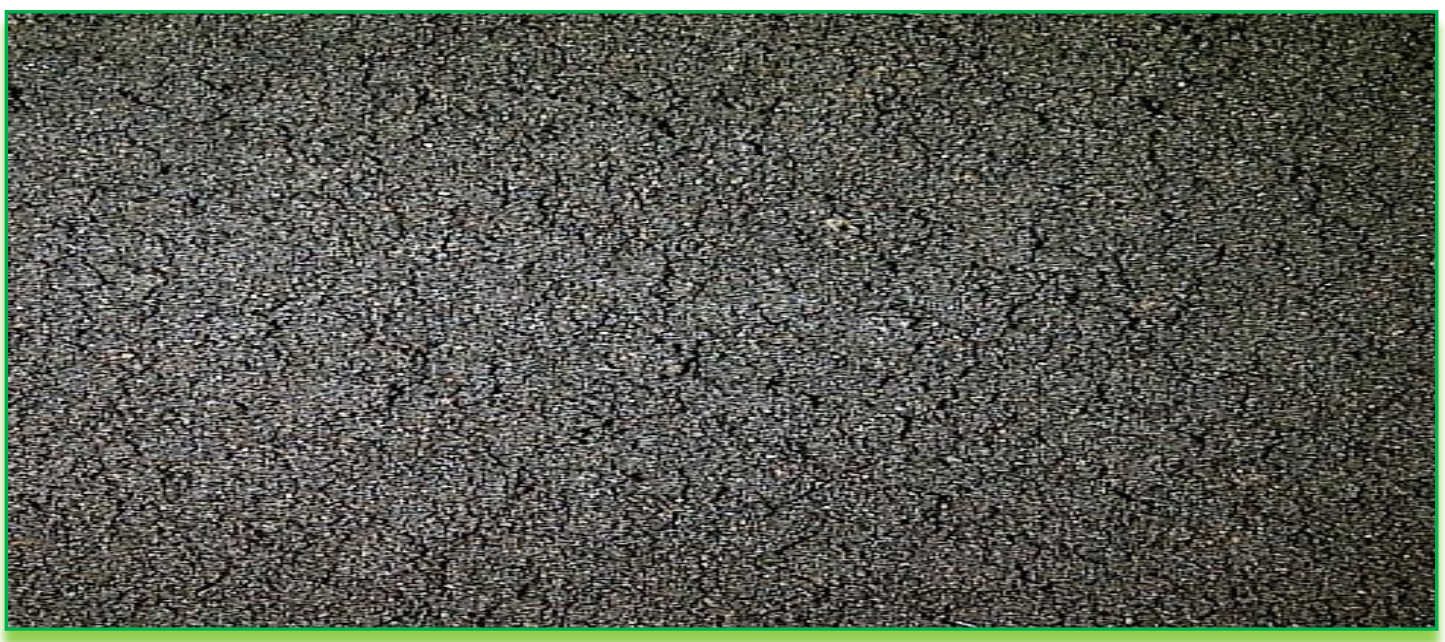

Plate X: Sample C on the fifth day of incubation

\section{Remediation Experiment}

Table 5 represents the results from the remediation experiment carried out for 14 days at temperatures of $30,35,40$ and $45^{\circ} \mathrm{C}$. The initial THC value of $25.48 \mathrm{mg} / \mathrm{L}$ and the same soil sample quantity of $500 \mathrm{~g}$ was used.

By the 3rd day, the remediation at $40^{\circ} \mathrm{C}$ indicated evidence of better performance with the lowest THC of 20.114. This trend changed after the 7 th day as the remediation at $45^{\circ} \mathrm{C}$ had the lowest THC of 10.273. The impact of weather is believed to be responsible for this phenomenon (Iqdal, 2003). This pattern continued till the 
final day of the experiment. Even though the impact of higher temperature on remediation efficiency was not evident for the first few days due to the fact that there was no significant degradation activity for the first few days, by the 14th day, it was evident that the sample at the highest temperature of $45^{\circ} \mathrm{C}$ performed better. The reason for this trend is hypothesised to be due to the impact of temperature on the rate of degradation. Microbial degradation increases as temperature increases. The moisture content of the soil also decreases as temperature increases (Iqdal, 2003). This reduces the available pollutant for adsorption thereby making the adsorption process easier and faster.

This trend is better observed graphically in Figure 1.

Plates XI and XII are pictorial views of the remediation experiment sample at 30 and $35^{\circ} \mathrm{C}$ respectively.

Table 5 Remediation Experiment at Various Temperatures

\begin{tabular}{ccccc}
\hline & $\mathbf{3 0} \mathbf{c}$ & $\mathbf{3 5}^{\mathbf{0}}$ & $\mathbf{4 0}^{\mathbf{0}}$ & $\mathbf{4 5}^{\mathbf{0}}$ \\
\hline INITIAL & 25.48 & 25.48 & 25.48 & 25.48 \\
$13 / 5 / 12$ & 25.331 & 25.200 & 25.062 & 25.031 \\
$14 / 5 / 12$ & 22.873 & 24.130 & 23.878 & 24.594 \\
$15 / 5 / 12$ & 22.507 & 22.703 & 20.114 & 22.834 \\
$16 / 5 / 12$ & 21.621 & 21.912 & 18.439 & 20.815 \\
$17 / 5 / 12$ & 20.973 & 20.551 & 16.744 & 18.611 \\
$18 / 5 / 12$ & 19.717 & 18.758 & 14.330 & 10.273 \\
$19 / 5 / 12$ & 18.434 & 17.118 & 12.712 & 9.880 \\
$20 / 5 / 12$ & 17.745 & 16.889 & 10.254 & 6.677 \\
$21 / 5 / 12$ & 14.668 & 13.703 & 8.044 & 4.419 \\
$22 / 5 / 12$ & 12.594 & 10.331 & 6.660 & 2.877 \\
$23 / 5 / 12$ & 9.668 & 7.818 & 5.908 & 2.608 \\
$24 / 5 / 12$ & 7.136 & 5.990 & 4.533 & 0.617 \\
$25 / 5 / 12$ & 5.512 & 2.584 & 1.744 & 0.228 \\
$26 / 5 / 12$ & 3.701 & 0.795 & 0.860 &
\end{tabular}

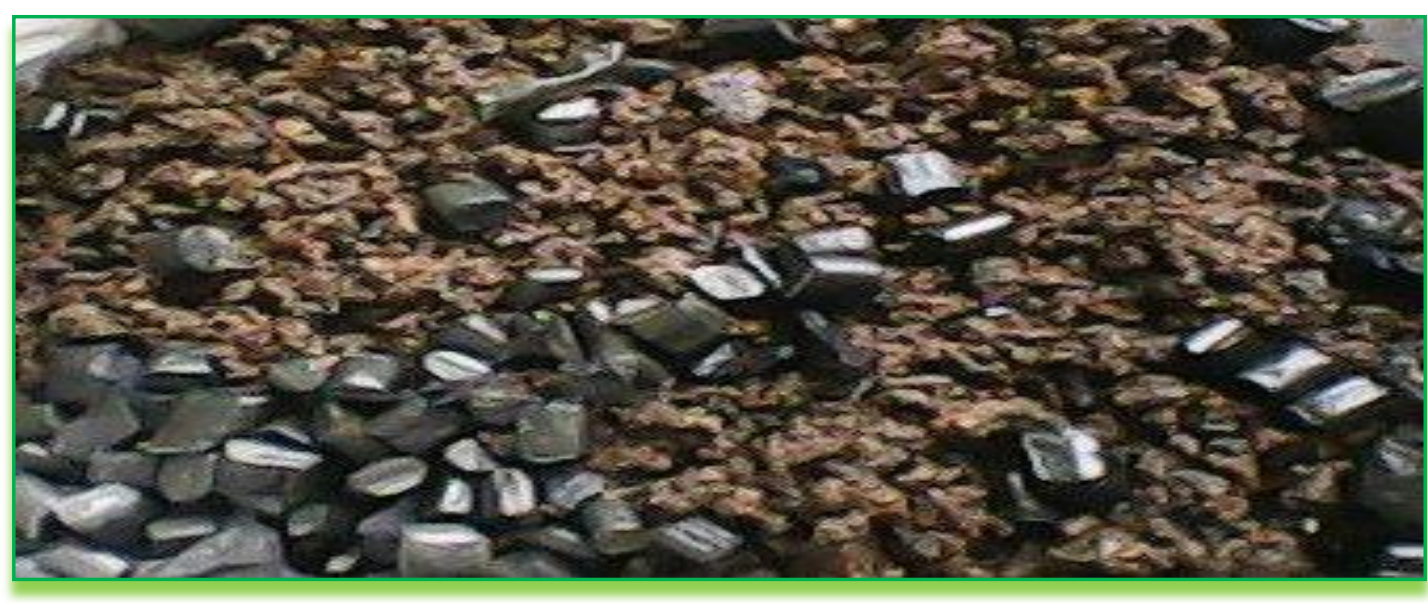

Plate XI: Sample for remediation at $30^{\circ} \mathrm{C}$

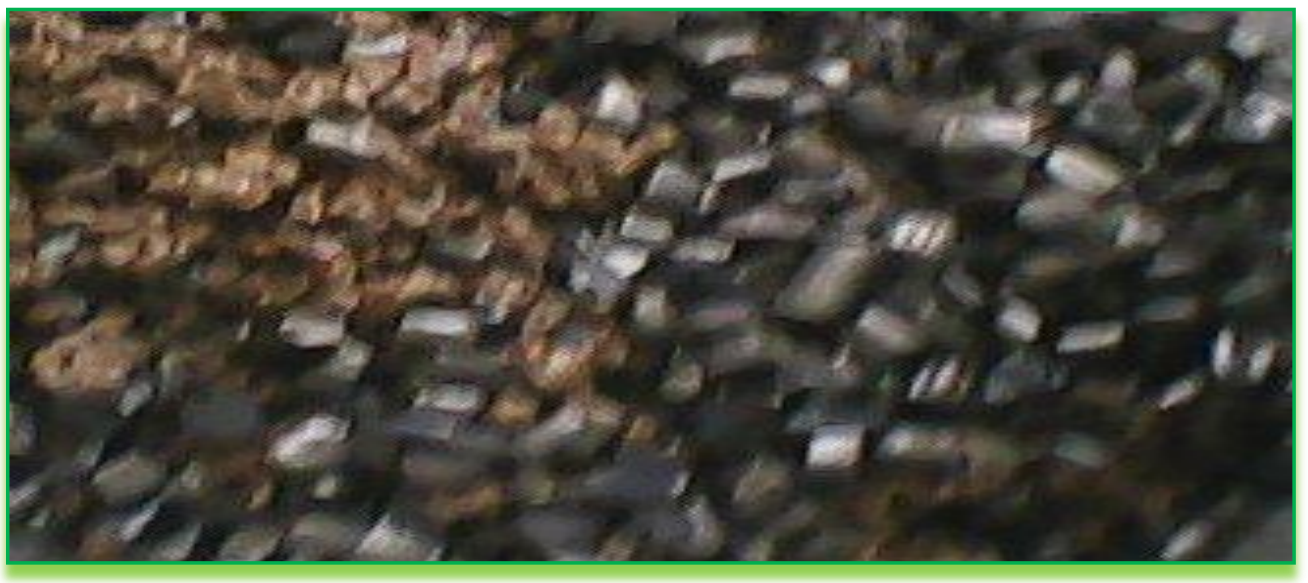

Plate XII: Pictorial sample of remediation at $35^{\circ} \mathrm{C}$ 


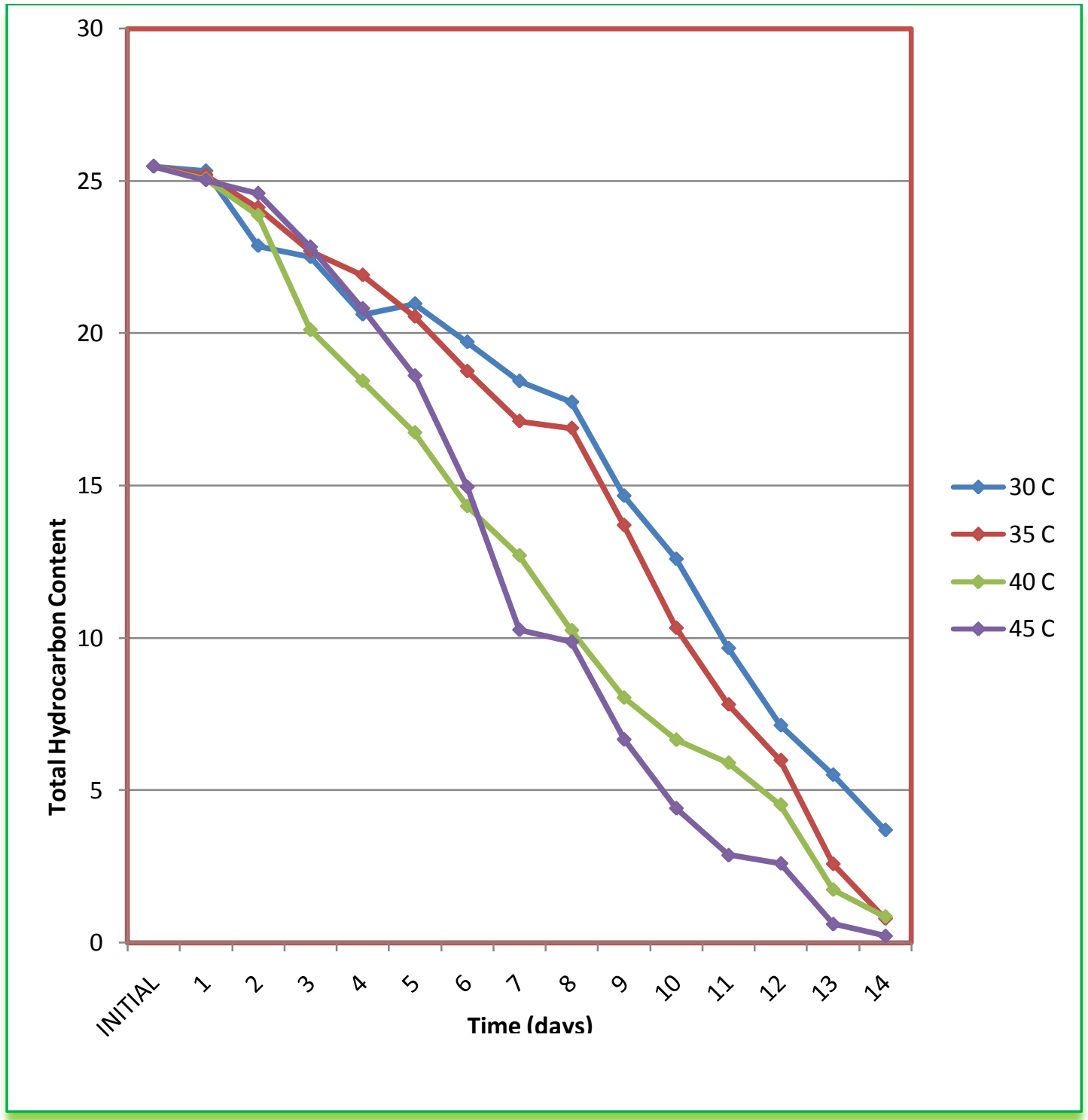

Figure 1: Remediation at different temperature

\section{Conclusions}

The research on remediation of a petroleum site in Nigeria using granulated activated carbon (GAC) was successfully carried out by characterization of the soil samples before and after pollution, characterization of the commercially obtained granular activated carbon before and after use as well as the remediation experiments. Graphical illustration of remediation at different temperatures show that microbial degradation increases as temperature increases. The moisture content of the soil also decreases as temperature increase. It can be concluded that hydrocarbon pollution leads to corresponding environmental impact on the soil which can be remediated by the use of Granular Activated Carbon (GAC).

\section{Acknowledgements}

I wish to express my profound love and appreciation to my wife, Mrs Rosemary Ameh, my beautiful daughter, Angel Ameh and my wonderful son, David Ameh who made the most important sacrifices and bore the burden of my absence throughout the research work. We made it!

\section{References}

[1]. Achebe, C. H., Nneke, U. C \& Anisiji, O. E (2012): Analysis of Oil Pipeline Failures in the Oil and Gas Industries in the Niger Delta of Nigeria. Published in the proceedings of the International MultiConference of Engineers and Computer Scientists, 2012. Vol. II. March 2012.

[2]. Bartelt-Hunt, S.L., Culver, T.B., Smith, J.A., Matott, L.S. and Rabideau, A.J. (2006): Optimal

[3]. design of a compacted soil liner containing sorptive amendments, Journal of Environmental Engineering-ASCE, 132, 769-776. 
[4]. Bes, C. and Mench, M. (2008): Remediation of copper-contaminated topsoils from a wood treatment facility using in situ stabilisation, Environmental Pollution, 156, 1128-1138.

[5]. Blowout (2012): Two More Dead in Rig Blowout off Nigeria. An Article published in the Blowout Spring Edition. Issue 84. 2012.

[6]. Castelo-Grande, T., Augusto, P.A., Monteiro, P., Estevez, A.M. and Barbosa, D. (2010):

[7]. Remediation of soils contaminated with pesticides: a review, International Journal of Environmental Analytical Chemistry, $\mathrm{p} 90$, 438-467.

[8]. DeSilva, F (2000): Activated Carbon Filtration. Published in Water Quality Products Magazine. January 2000.

[9]. Iqbal, J (2003). Effect of Temperature on Efficiency of in situ Bioremediation Technology: A Laboratory Microcosm and Field Study. A Thesis submitted to the Graduate Faculty of the Louisiana State University. August 2003.

[10]. Lowry G.V, Murphy P.J, Marquette, A. and Reible D, (2006): Sorbent-amended "active" sediment caps for in-place management of PCB-contaminated sediments. Contaminated Soils, Sediments and Water, 10, 379-391.

[11]. Murphy, P., Marquette, A., Reible, D and Lowry, G.V (2006): Predicting the performance of activated carbon coke, and soilamended thin layer sediment caps. Journal of Environmental Engineering-ASCE, 132, 787-794.

[12]. Nwilo, P.C. \& O.T. Badejo, (2005): Oil Spill Problems and Management in the Niger Delta. International Oil Spill Conference, Miami, Florida, USA.

[13]. Oloruntegbe, K. O., Akinsete, M. A \& Odutuyi, M. O (2009). Fifty years of Oil Exploration in Nigeria: Physico-chemical Impacts and Implication for Environmental Accounting and Development. Published in the Journal of Applied Sciences Research. Vol. 5 (12), pp 2131 - 2137. 2009.

[14]. Oruonye, E. D (2012) Multinational Oil Corporations in Sub Saharan Africa: An Assessment of the Impacts of Globalization. Published by the International Journal of Humanities and Social Science. Vol. 2, No. 4, February 2012.

[15]. Price Forbes (2012): Fire on KS Endeavor Jack-up Offshore Nigeria. Published in the Energy Newsletter, February 2012.

[16]. Ying, G.G., Kookana R.S. \& Mallavarpu M. (2005): Release behavior of triazine residues in stabilized contaminated soils. Environmental Pollution, 134, 71-77.

[17]. Zabbey, N (2009): Impacts of Oil Pollution on Livelihoods in Nigeria. A Paper presented at the conference on "Petroleum and Pollution - how does that impact human rights? April 2009. 